Gynecologic and

Obstetric Investigation

\title{
Decidual Bleeding as a Cause of Spontaneous Hemoperitoneum in Pregnancy and Risk of Preterm Birth
}

\author{
Marit C.I. Lier ${ }^{a}$ Ivo A. Brosens ${ }^{b}$ Velja Mijatovic ${ }^{a}$ Marwan Habiba $^{c}$ \\ Giuseppe Benagiano $^{\text {d }}$ \\ aVU University Medical Centre, Endometriosis Centre VUmc, Department of Reproductive Medicine, Amsterdam, \\ The Netherlands; ${ }^{b}$ Leuven Institute for Fertility and Embryology, Leuven, Belgium; ' Department of Obstetrics and \\ Gynecology, University Hospitals of Leicester, Leicester Royal Infirmary, Leicester, UK; ${ }^{d}$ Department of Gynecology, \\ Obstetrics and Urology, Sapienza, University of Rome, Rome, Italy
}

\section{Keywords}

Spontaneous hemoperitoneum - Endometriosis .

Deciduosis · Pregnancy complications · In vitro fertilization

\begin{abstract}
Background: Spontaneous hemoperitoneum in pregnancy (SHiP) is a rare, life-threatening event, particularly relevant to women with endometriosis or deciduosis. Methods: To determine the type of lesions leading to SHiP, a literature search was conducted among all published SHiP cases. From a total of 1,339 publications, information on pathological findings at the bleeding site with histological data was found in 24 case reports (16 pregnant, 8 postpartum). Results: Among pregnant women ( $81 \%$ primigravida), $75 \%$ had a diagnosis of endometriosis and $25 \%$ of deciduosis. Among postpartum women (38\% primiparous), $63 \%$ had a diagnosis of deciduosis and $25 \%$ of endometriosis. In all cases except one, decidual cells, with or without glandular structures, were present at the bleeding site. Decidual vessels were described in 7 cases and all exhibited vascular changes, including distension of the lumen, medial disorganization, or loss of vascular integrity. These vessels were significantly different from arteries seen in the secretory endometrium, showing that structural modifications take place during the initial stage of
\end{abstract}

\section{KARGER}

(C) 2017 S. Karger AG, Basel

E-Mail karger@karger.com

www.karger.com/goi the remodelling of placental bed spiral arteries. Conclusions: During pregnancy, a link seems to exist between ectopic decidualization, particularly that occurring in endometriotic foci, and occurrence of SHiP. In addition, subclinical decidual bleeding may be a potential risk factor for preterm labour.

(c) 2017 S. Karger AG, Basel

\section{Introduction}

Recent reports focused attention on the rare, yet lifethreatening occurrence of spontaneous hemoperitoneum in pregnancy (SHiP). This may be particularly relevant to women with endometriosis or deciduosis if they are undergoing in vitro fertilization (IVF) treatment. This dramatic complication has been associated with high perinatal morbidity and even mortality, but the trigger of the spontaneous bleeding has not been established $[1,2]$. Although the aetiology of SHiP remains unknown and may be multifactorial, several theories have been proposed to explain the rare complication (Table 1 ). The early reports describing

The study was conducted at the VU University Medical Centre, Amsterdam, the Netherlands.

Ivo A. Brosens $\mathrm{MD}, \mathrm{PhD}$

Leuven Institute for Fertility and Embryology

Tiensevest 168

BE-3000 Leuven (Belgium)

E-Mail ivo.brosens@ @ed.kuleuven.be 
Table 1. Hypotheses formulated in the literature on the cause of spontaneous hemoperitoneum in pregnancy

- Sudden increases in venous pressures associated with muscular activity, defecation, coughing, lifting, or coitus [3]

- Tortuous path of the uterine and ovarian veins, their lack of valves and their distension with elevated intraluminal pressure, although the presence of some additional vascular defect was postulated [4]

- Chronic inflammation due to endometriosis making the utero-ovarian vessels more friable, or the resultant adhesions creating further tension to these vessels as the uterus expands during pregnancy $[5,6]$

- Hemodynamic factors, as well as increased hormonal effects caused by pregnancy leading to structural vessel changes able to impair the arterial wall [7]

- Necrosis and shedding of the decidualized endometriotic lesions during the third trimester of pregnancy or following delivery [8]

- Erosion of the uterine artery or its branches by endometriosis [9]

- Possible relation between the site of placental implantation and rupture of uterine vessels [10]

- Potential 2-step process of uterine artery rupture starting with circumscribed hematoma of the broad ligament causing compression of adjacent anatomic structures (ureter, bowel), followed by rupture into the abdominal cavity [11]

- Progesterone resistance in endometriosis could trigger involution of the ectopic decidua surrounding uterine vessels, leading to peritoneal bleeding of unpredictable severity [12]

this complication suggested venous rupture due to a sudden increase in venous pressure associated with muscular activity, defecation, coughing, lifting or coitus [3]. Increased pelvic congestion and blood flow, the tortuous path of the uterine and ovarian veins, their lack of valves and their distension with elevated intraluminal pressure may provide vascular conditions for the dramatic event [4].

For a better understanding of the pathogenesis of SHiP and in the absence of systematic studies of vascular changes occurring at the site of bleeding, we reviewed all case reports in search of information on pathological events at the site of bleeding.

\section{Material and Methods}

\section{Search Strategy and Analysis}

A Scopus search, undertaken on July 13, 2015, using the term "spontaneous hemoperitoneum in pregnancy," produced a total of 480 publications, starting with the publication by Hodgkinson and Christensen [3] in 1950. The search was extended by probing further into the list of references for additional case reports.

We also undertook a PubMed search using the terms "hemoperitoneum and pregnancy" on February 1, 2016. This yielded 859 articles. We excluded cases related to uterine ruptures, ectopic pregnancies, ruptured cysts and other recognized causes of intraabdominal bleeding. After reading the abstracts and, if relevant, the full papers, original cases were identified that included a description of the histopathology taken from the bleeding site. This search was limited to articles published in English. Although the purpose of this review is to examine the occurrence of hemoperitoneum during pregnancy, reports of SHiP during the postpartum period (up to 6 weeks after delivery) have been included as well.
Finally, we searched for relevant articles on "deciduosis," defined by the presence of foci of decidualized mesenchymal cells, but the absence of glandular cells, in the sub-peritoneum of pelvic or abdominal structures during pregnancy [13].

\section{Results}

The search identified 91 cases of SHiP published between 1950 and 2016. Of these, 24 case reports included a histological description from a biopsy obtained from the bleeding site. In one postpartum case, the site of bleeding was not identified. The series includes 16 cases during pregnancy and 8 cases of SHiP on the day of delivery, or during the postpartum period.

\section{Vascular Pathology at the Site of Bleeding}

Histopathology findings of available biopsies are summarized in Table 2. All case reports, except the one obtained in the postpartum period, indicate the presence of decidual cells with or without glandular structures, at the site of bleeding. Seven case reports included a description of blood vessels present in the biopsy.

Three of the 16 biopsies obtained during pregnancy included information about blood vessels at the bleeding site(s). Aziz et al. [24] described a focus of endometriosis and decidualization in a woman who was 30 weeks into her first pregnancy and demonstrated the presence of very thin-walled blood vessels in the decidualized stroma. Mizumoto et al. [6] documented the presence of ruptured vessels on the serosal surface of the uterine fundus at
314

Gynecol Obstet Invest 2017;82:313-321 DOI: $10.1159 / 000468933$
Lier/Brosens/Mijatovic/Habiba/

Benagiano 
Table 2. Histopathology of biopsies from the bleeding site in cases of spontaneous hemoperitoneum during pregnancy

\begin{tabular}{|c|c|c|}
\hline Author & Site of biopsy & Histopathology \\
\hline \multicolumn{3}{|l|}{ Pregnancy } \\
\hline Lier et al. [14], 2017 (case II) & Near left ovary, bowel & Endometriotic tissue, decidual changes \\
\hline Lier et al. [14], 2017 (case IX) & Bladder peritoneum & Endometriotic tissue, decidual changes \\
\hline Lier et al. [14], 2017 (case XI) & Bladder peritoneum, pouch of Douglas, bowel & Endometriotic tissue, decidual changes \\
\hline Loh et al. [15], 2015 & Left fallopian tube & Endometriosis \\
\hline Cozzolino et al. [16], 2015 & Right adnexa & Endometriotic tissue, decidual changes \\
\hline Aggarwal et al. [17], 2014 & Left fallopian tube & $\begin{array}{l}\text { Hemorrhagic foci of endometriosis, } \\
\text { decidual changes, atrophic dilated } \\
\text { glands }\end{array}$ \\
\hline De Vincenzo et al. [12], 2013 & Bowel, lymph nodes & Endometriotic tissue, decidual changes \\
\hline Kondoh et al. [18], 2012 & Uterine surface/peritoneum, omentum & Deciduosis \\
\hline Reif et al. [19], 2011 & Left ovary (partial), left fallopian tube, adhesions & Decidualized endometriosis \\
\hline Brouckaert et al. [20], 2010 & Right adnexa, parametrium & Endometriotic tissue, decidual changes \\
\hline Bouet et al. [21], 2009 & Left broad ligament, left adnexa/parametrium & Decidualized endometriosis \\
\hline Grunewald and Jördens [22], 2009 & Right sacro-uterine ligament & Endometriosis \\
\hline Katorza et al. [23], 2007 (case II) & Right adnexa & Endometriotic tissue, decidual changes \\
\hline Aziz et al. [24], 2004 & Left broad ligament/parametrium & $\begin{array}{l}\text { Endometriotic tissue, decidual changes, } \\
\text { thin-walled vessels }\end{array}$ \\
\hline Mizumoto et al. [6], 1996 & Uterine surface & $\begin{array}{l}\text { Endometriotic tissue, decidual changes, } \\
\text { distended vessel with disintegrated wall }\end{array}$ \\
\hline Doyle and Philips [25], 1957 & $\begin{array}{l}\text { Peritoneal lesion right lateral pelvic wall/pouch of } \\
\text { Douglas }\end{array}$ & Decidual and vascular changes \\
\hline \multicolumn{3}{|l|}{ Intrapartum and postpartum } \\
\hline Lier et al. [14], 2017 (case IV) & Left uterovesical ligament & $\begin{array}{l}\text { Haemorrhagic foci of endometriosis, } \\
\text { decidual changes, distended and } \\
\text { angiomatous tissue }\end{array}$ \\
\hline Zhang and Lou [26], 2015 & Right ovary (cyst) & Endometriosis, decidualization \\
\hline Boztosun et al. [27], 2012 & Left ovary & Ectopic decidualization \\
\hline Gao et al. [28], 2010 & Pelvic adhesions & Endometriosis, decidual changes \\
\hline O’Leary [29], 2005 & Adnexa (bilateral) & Decidualization, vascular intrusion \\
\hline Richter et al. [30], 1983 & Uterine surface, adnexa (bilateral), parametrium & Decidual tissue \\
\hline Sabatelle and Winger [31], 1973 & Uterine surface & $\begin{array}{l}\text { Decidual changes, distended ruptured } \\
\text { vessels }\end{array}$ \\
\hline Hulme-Moir and Ross [32], 1969 & Omentum & Decidual tissue, vascular changes \\
\hline
\end{tabular}

20 weeks in a woman during her first pregnancy. Histology demonstrated an intense decidual reaction. The blood vessels were distended and exhibited disintegration of the vessel wall. Doyle and Philip [25] reported the autopsy finding of a very large quantity of blood and blood

Decidual Bleeding in Pregnancy clots distending the peritoneal cavity of a 37 -year-old woman who had SHiP with her first pregnancy. They identified a $2.5 \times 2 \mathrm{~cm}$ oval-shaped peritoneal lesion with raised edges on the right side of the pouch of Douglas. Microscopically, this exhibited haemorrhagic decidual 
tissue without chorionic villi. The blood vessels were distended and had a highly disorganized wall. This area with very vascular decidual reaction was presumed to be the source of the fatal haemorrhage.

Four of the 8 case reports with biopsies obtained postpartum included description of vasculature. Lier et al. [14] described a case of late postpartum SHiP in a patient with ovarian endometriosis. Histologically, there was a vascular lesion with multiple distended vessels and haemorrhagic deposits. O'Leary [29] published one case of massive postpartum SHiP in which, following supracervical hysterectomy, it was possible to identify the origin of brisk bleeding as a tumour-like mass. Bleeding was controlled by clamping and ligation of the left uterine artery at its origin from the hypogastric artery. Bilateral salpingo-oophorectomy was performed because of a presumptive diagnosis of a malignant lesion with multiple tumour-like masses located on both ovaries and on the left pelvic sidewall. Histopathology confirmed bilateral ovarian endometriosis with extensive decidualization but no malignant degeneration. A section of the hypogastric artery was examined: this exhibited decidualized stroma protruding into the large distended arterial lumen. Sabatelle and Winger [31] reported a case of severe intrapartum SHiP arising from a focus of ectopic deciduosis. The serosal surface over the posterior lower uterine segment was roughened and exhibited marked decidual reaction with large blood-filled sinuses communicating with the surface. Multiple sections through the uterine wall revealed no evidence of laceration or haemorrhage within the myometrium. Hulme-Moir and Ross [32] reported a case of postpartum SHiP presenting with abdominal pain 1 week after delivery. The woman had haemorrhagic appendices epiploicae in the transverse colon. Omental biopsy showed multiple small, well-defined foci of decidual cells in the fat immediately below the serosa. The small vessels were dilated and there was interstitial haemorrhage and early necrosis of some of the decidual cells. There were no glandular structures suggestive of endometriosis.

\section{Clinical Features of SHiP}

As mentioned, the search identified 16 women with SHiP during pregnancy and 8 women with SHiP on the day of delivery, or during the postpartum period (Table 3), from whom histological reports were available. Age in the first group ranged between 25 and 38 years and in the second group between 25 and 41 years.

Among women with SHiP during pregnancy, 13 (81\%) were primigravida, whereas in the second group, 3 (38\%) had delivered for the first time. In the pregnant group, all

316

Gynecol Obstet Invest 2017;82:313-321 DOI: $10.1159 / 000468933$

DOI: $10.1159 / 000468933$ had the diagnosis of endometriosis $(75 \%)$ or deciduosis $(25 \%)$, while in the intrapartum or postpartum group, $5(63 \%)$ had the diagnosis of deciduosis and $2(25 \%)$ of endometriosis. No information was available on the eighth case.

SHiP occurred in the pregnancy group between weeks 17 and 33 with a median of week 26 and was associated with a stillbirth or neonatal death rate of $56 \%$.

\section{Discussion}

\section{Endometriosis and Deciduosis Are Associated with}

Decidual Bleeding

Histopathology of the 24 biopsies obtained from the bleeding site in women with $\mathrm{SHiP}$ documented in all cases the presence of decidualized stromal cells. Decidual vessels were described in 7 cases and invariably these exhibited vascular changes, including distension of the lumen, medial disorganization, or loss of vascular integrity. Craven et al. [33] documented that decidual arteries were significantly different from arteries seen in the secretory endometrium, leading to the conclusion that structural modifications take place during the initial stage of physiological remodelling of the placental bed spiral arteries, before the vessel is affected by intravascular and interstitial trophoblast invasion. The early arterial changes are characterized by more endothelial basophilia, vacuolization, loss of elasticity and dilatation. In addition, some vessels show disorganized or hypertrophied smooth muscle layers. Similar structural alterations occur in endometrial arterioles in the decidua parietalis of intrauterine pregnancies and in cases with ectopic pregnancy.

This clearly shows that in the placental bed, decidual spiral artery remodelling starts before the beginning of cellular interaction between the vessel and the intravascular or interstitial trophoblast. These physiological changes transform the decidual and myometrial segments of some 50 spiral arteries in the placental bed and allow an appropriate blood flow into the placenta during the progression of pregnancy [34].

SHiP in patients with endometriosis raises the possibility of multiple bleeding sites in the pelvis. All of these need to be identified in order to achieve haemostasis. This can be very challenging, as the large uterus obstructs access to the posterior pelvic cavity during pregnancy. The posterior pouch of Douglas can also be obstructed by the presence of endometriosis-related adhesions and multiple endometriotic implants.
Lier/Brosens/Mijatovic/Habiba/ Benagiano 
Table 3. Clinical data

\begin{tabular}{|c|c|c|c|c|c|c|c|c|c|}
\hline Author & $\begin{array}{l}\text { Age, } \\
\text { years }\end{array}$ & Para & $\begin{array}{l}\text { Endometriosis/ } \\
\text { deciduosis, ART }\end{array}$ & Site of bleeding & $\begin{array}{l}\text { Blood } \\
\text { loss, } \mathrm{mL}\end{array}$ & $\begin{array}{l}\text { Gestational } \\
\text { age, weeks }\end{array}$ & $\begin{array}{l}\text { Type of surgical } \\
\text { intervention }\end{array}$ & $\begin{array}{l}\text { Birth } \\
\text { weight, g }\end{array}$ & Outcome \\
\hline \multicolumn{10}{|l|}{ Pregnancy } \\
\hline $\begin{array}{l}\text { Lier et al. [14], } \\
2017 \text { (case II) }\end{array}$ & 35 & 0 & $\begin{array}{l}\mathrm{E} \\
\mathrm{IVF}\end{array}$ & $\begin{array}{l}\text { Descending colon, } \\
\text { rectosigmoid, near left } \\
\text { ovary }\end{array}$ & 1,100 & 28 & $\begin{array}{l}\text { Caesarean section, } \\
\text { resection, } \\
\text { compression }\end{array}$ & 1,245 & Live birth \\
\hline $\begin{array}{l}\text { Lier et al. [14], } \\
2017 \text { (case IX) }\end{array}$ & 31 & 0 & $\begin{array}{l}\mathrm{E} \\
-\end{array}$ & $\begin{array}{l}\text { Posterior right broad } \\
\text { ligament/right uterine } \\
\text { vein }\end{array}$ & 3,000 & 33 & $\begin{array}{l}\text { Caesarean section, } \\
\text { suture-ligation }\end{array}$ & 2,400 & Live birth \\
\hline $\begin{array}{l}\text { Lier et al. [14], } \\
2017 \text { (case XI) }\end{array}$ & 37 & 0 & $\begin{array}{l}\mathrm{E} \\
\mathrm{IVF}\end{array}$ & $\begin{array}{l}\text { Right broad ligament, } \\
\text { right round ligament, left } \\
\text { uterosacral ligament, } \\
\text { bladder }\end{array}$ & 1,750 & 30 & $\begin{array}{l}\text { Caesarean section, } \\
\text { suture-ligation }\end{array}$ & 1,620 & Live birth \\
\hline $\begin{array}{l}\text { Loh et al. [15], } \\
2015\end{array}$ & 31 & 0 & $\begin{array}{l}\mathrm{E} \\
\mathrm{IVF}\end{array}$ & Left fallopian tube & 3,500 & 21 & $\begin{array}{l}\text { Hysterotomy, } \\
\text { salpingectomy }\end{array}$ & NA & $\begin{array}{l}1 \times \text { stillbirth, } \\
1 \times \text { neonatal } \\
\text { death }\end{array}$ \\
\hline $\begin{array}{l}\text { Cozzolino } \\
\text { et al. [16], } 2015\end{array}$ & 33 & 1 & $\begin{array}{l}\mathrm{E} \\
-\end{array}$ & $\begin{array}{l}\text { Right ovary and right } \\
\text { posterior side uterus }\end{array}$ & 1,500 & 29 & $\begin{array}{l}\text { Caesarean section, } \\
\text { adnexectomy, } \\
\text { coagulation, } \\
\text { suture-ligation }\end{array}$ & 1,390 & Live birth \\
\hline $\begin{array}{l}\text { Aggarwal } \\
\text { et al. [17], } 2014\end{array}$ & 31 & 0 & $\begin{array}{l}\mathrm{E} \\
\mathrm{IVF}\end{array}$ & $\begin{array}{l}\text { Left fallopian tube, } \\
\text { adhesions, surface uterus }\end{array}$ & 2,200 & 22 & $\begin{array}{l}\text { Caesarean section, } \\
\text { salpingectomy }\end{array}$ & NA & $2 \times$ stillbirth \\
\hline $\begin{array}{l}\text { De Vincenzo } \\
\text { et al. [12], } 2013\end{array}$ & 33 & 0 & $\begin{array}{l}\mathrm{E} \\
-\end{array}$ & $\begin{array}{l}\text { Posterior side uterus, left } \\
\text { uterine artery, bowel, } \\
\text { lymph nodes }\end{array}$ & 2,500 & 24 & $\begin{array}{l}\text { Caesarean section, } \\
\text { bowel resection, } \\
\text { suture-ligation }\end{array}$ & NA & Stillbirth \\
\hline $\begin{array}{l}\text { Kondoh } \\
\text { et al. [18], } 2012\end{array}$ & 31 & 0 & $\begin{array}{l}\mathrm{D} \\
-\end{array}$ & $\begin{array}{l}\text { Posterior side uterus, } \\
\text { peritoneal and omental } \\
\text { surface }\end{array}$ & $\begin{array}{l}\text { Large } \\
\text { (TBL: 2,475) }\end{array}$ & 29 & Caesarean section & 1,318 & Live birth \\
\hline $\begin{array}{l}\text { Reif } \\
\text { et al. [19], } 2011\end{array}$ & 25 & 0 & $\begin{array}{l}\mathrm{E} \\
\mathrm{IVF}\end{array}$ & $\begin{array}{l}\text { Left ovary (partial), left } \\
\text { fallopian tube, adhesions }\end{array}$ & 1,500 & 27 & $\begin{array}{l}\text { Caesarean section, } \\
\text { cystectomy, } \\
\text { tubectomy }\end{array}$ & $\begin{array}{l}1,190 \\
890\end{array}$ & $2 \times$ live birth \\
\hline $\begin{array}{l}\text { Brouckaert } \\
\text { et al. [20], } 2010\end{array}$ & 33 & 0 & $\begin{array}{l}\mathrm{E} \\
\mathrm{IVF}\end{array}$ & $\begin{array}{l}\text { Right ovary (1st episode); } \\
\text { right ovary, right broad } \\
\text { ligament ( } 2 \text { nd episode) }\end{array}$ & $\begin{array}{l}2,600(1 \mathrm{st}) \\
3,500(2 \mathrm{nd})\end{array}$ & 17 & $\begin{array}{l}\text { Adnexectomy, } \\
\text { hysterectomy with } \\
\text { fetus in situ, } \\
\text { coagulation, } \\
\text { suture-ligation }\end{array}$ & NA & Stillbirth \\
\hline $\begin{array}{l}\text { Bouet } \\
\text { et al. [21], } 2009\end{array}$ & 33 & 0 & $\begin{array}{l}\mathrm{D} \\
-\end{array}$ & $\begin{array}{l}\text { Left broad ligament/ } \\
\text { parametrium }\end{array}$ & 700 & 24 & $\begin{array}{l}\text { Adnexectomy, } \\
\text { caeserean section }\end{array}$ & NA & Stillbirth \\
\hline $\begin{array}{l}\text { Grunewald } \\
\text { et al. [22], } 2009\end{array}$ & 33 & 2 & $\begin{array}{l}\mathrm{E} \\
-\end{array}$ & $\begin{array}{l}\text { Right sacro-uterine } \\
\text { ligament }\end{array}$ & 900 & 27 & $\begin{array}{l}\text { Coagulation, } \\
\text { hemostasic agents }\end{array}$ & 4,665 & $\begin{array}{l}\text { Live birth } \\
\text { ( } 42 \text { weeks) }\end{array}$ \\
\hline $\begin{array}{l}\text { Katorza et al. [23], } \\
2007 \text { (case II) }\end{array}$ & 31 & 1 & $\begin{array}{l}\mathrm{E} \\
\mathrm{IVF}\end{array}$ & $\begin{array}{l}\text { Right adnexa, } \\
\text { parametrium }\end{array}$ & 3,000 & 26 & Adnexectomy & NA & $\begin{array}{l}\text { Pregnancy } \\
\text { termination } \\
\text { (parental } \\
\text { request) }\end{array}$ \\
\hline Aziz et al. [24], 2004 & 30 & 0 & $\begin{array}{l}\mathrm{E} \\
-\end{array}$ & $\begin{array}{l}\text { Left broad ligament/ } \\
\text { parametrium, left ovary }\end{array}$ & 3,000 & 20 & $\begin{array}{l}\text { Adnexectomy, } \\
\text { caeserean section }\end{array}$ & NA & Stillbirth \\
\hline $\begin{array}{l}\text { Mizumoto } \\
\text { et al. [6], } 1996\end{array}$ & 28 & 0 & $\begin{array}{l}\text { E, D } \\
-\end{array}$ & $\begin{array}{l}\text { Enlarged, dilated veins/ } \\
\text { serosa uterine fundus }\end{array}$ & 4,000 & 28 & $\begin{array}{l}\text { Suture ligation, } \\
\text { caesarean section }\end{array}$ & 1,250 & $\begin{array}{l}\text { Neonatal } \\
\text { death }\end{array}$ \\
\hline $\begin{array}{l}\text { Doyle and Phillips [25], } \\
1957\end{array}$ & 37 & 0 & $\begin{array}{l}\mathrm{D} \\
-\end{array}$ & $\begin{array}{l}\text { Right lateral pelvic } \\
\text { wall/pouch of Douglas }\end{array}$ & Large & 33 & $\begin{array}{l}\text { Maternal death } \\
\text { (autopsy) }\end{array}$ & NA & $\begin{array}{l}\text { Fetal death } \\
\text { (autopsy) }\end{array}$ \\
\hline \multicolumn{10}{|c|}{ Intrapartum and postpartum } \\
\hline $\begin{array}{l}\text { Lier et al. [14], } 2017 \\
\text { (case IV) }\end{array}$ & 33 & 1 & $\begin{array}{l}\mathrm{D} \\
-\end{array}$ & $\begin{array}{l}\text { Left uterovesical } \\
\text { ligament }\end{array}$ & 2,000 & $\begin{array}{l}\text { PP } \\
\text { Day } 12\end{array}$ & $\begin{array}{l}\text { Suture-ligation, } \\
\text { haemostatic } \\
\text { agents }\end{array}$ & NA & NA \\
\hline
\end{tabular}


Table 3. (continued)

\begin{tabular}{|c|c|c|c|c|c|c|c|c|c|}
\hline Author & $\begin{array}{l}\text { Age, } \\
\text { years }\end{array}$ & Para & $\begin{array}{l}\text { Endometriosis/ } \\
\text { deciduosis, ART }\end{array}$ & Site of bleeding & $\begin{array}{l}\text { Blood } \\
\text { loss, } \mathrm{mL}\end{array}$ & $\begin{array}{l}\text { Gestational } \\
\text { age, weeks }\end{array}$ & $\begin{array}{l}\text { Type of surgical } \\
\text { intervention }\end{array}$ & $\begin{array}{l}\text { Birth } \\
\text { weight, g }\end{array}$ & Outcome \\
\hline $\begin{array}{l}\text { Zhang and Lou [26], } \\
2015\end{array}$ & 25 & 0 & $\begin{array}{l}\mathrm{E} \\
-\end{array}$ & $\begin{array}{l}\text { Ovarian cyst, posterior } \\
\text { uterine wall vessels }\end{array}$ & 2,500 & Intrapartum & $\begin{array}{l}\text { Caesarean section, } \\
\text { adhesiolysis, } \\
\text { cystectomy, suture- } \\
\text { ligation }\end{array}$ & Unknown & Livebirth \\
\hline $\begin{array}{l}\text { Boztosun et al. [27], } \\
2012\end{array}$ & 25 & 0 & $\begin{array}{l}\mathrm{E} \\
-\end{array}$ & No active bleeding & 1,500 & $\begin{array}{l}\text { PP } \\
\text { Day } 0\end{array}$ & $\begin{array}{l}\text { Explorative } \\
\text { laparotomy: no } \\
\text { interventions }\end{array}$ & NA & NA \\
\hline Gao et al. [28], 2010 & 29 & 1 & Unknown & $\begin{array}{l}\text { Bilateral pelvic and } \\
\text { ovarian adhesions, left } \\
\text { uterine artery }\end{array}$ & 2,000 & $\begin{array}{l}\text { PP } \\
\text { Day } 3\end{array}$ & $\begin{array}{l}\text { Ligation left } \\
\text { internal iliac } \\
\text { artery }\end{array}$ & NA & NA \\
\hline O’Leary [29], 2005 & 41 & 1 & $\begin{array}{l}\mathrm{D} \\
-\end{array}$ & $\begin{array}{l}\text { Left pelvic sidewall } \\
\text { (diffuse) }\end{array}$ & 2,000 & $\begin{array}{l}\text { PP } \\
\text { Day } 11\end{array}$ & $\begin{array}{l}\text { Hysterectomy, } \\
\text { ligation left uterine } \\
\text { artery, bilateral } \\
\text { adnexectomy }\end{array}$ & NA & NA \\
\hline $\begin{array}{l}\text { Richter et al. [30], } \\
1983\end{array}$ & 36 & 3 & $\begin{array}{l}\mathrm{D} \\
-\end{array}$ & $\begin{array}{l}\text { Posterior left broad } \\
\text { ligament/parametrium }\end{array}$ & 800 & $\begin{array}{l}\text { PP } \\
\text { Day } 0\end{array}$ & $\begin{array}{l}\text { Hysterectomy, } \\
\text { bilateral } \\
\text { salpingo- } \\
\text { oophorectomy }\end{array}$ & NA & NA \\
\hline $\begin{array}{l}\text { Sabatelle and Winger } \\
{[31], 1973}\end{array}$ & 23 & 0 & $\begin{array}{l}\mathrm{D} \\
-\end{array}$ & $\begin{array}{l}\text { (Bloodvessels) posterior } \\
\text { uterine wall }\end{array}$ & 3,000 & $\begin{array}{l}\text { PP } \\
\text { Day } 0\end{array}$ & Hysterectomy & NA & Stillbirth \\
\hline $\begin{array}{l}\text { Hulme-Moir and Ross } \\
{[32], 1969}\end{array}$ & 25 & 1 & $\begin{array}{l}\mathrm{D} \\
-\end{array}$ & Omentum & Unknown & $\begin{array}{l}\text { PP } \\
\text { Day } 9\end{array}$ & $\begin{array}{l}\text { Explorative } \\
\text { laparotomy }\end{array}$ & NA & NA \\
\hline
\end{tabular}

ART, assisted reproductive techniques; D, deciduosis; E, endometriosis; IVF, in vitro fertilization; NA, not applicable; PP, postpartum; TBL, total blood loss.

The phenomenon of "deciduosis," defined as extrauterine decidualization of stromal cells, has been well described in the peritoneum, cervix and ovary. Although its formation under hormonal stimulation suggests a relationship with endometriosis, the clinico-pathological process is distinct and deciduosis does not always indicate underlying endometriosis [35]. Büttner et al. [36] investigated biopsies of tissues taken from the omentum $(n=$ $60)$ and various abdominal organs $(n=48)$ at the time of caesarean section or ectopic pregnancy at different gestational ages. Focal or diffuse deciduosis was observed in all cases. Vacuolar degeneration and fragmentation, which are manifestations of regressive changes of the decidual cells, were noted in cases of advanced pregnancy. In more than $80 \%$ of cases, blood vessels or the area with ectopic decidua showed proliferation and enlargement when compared to areas of normal fat tissue. Immunohistochemistry demonstrated hormone-induced metaplasia of the sub-mesothelial mesenchyme. The exact onset and involution of extra-uterine decidua are not known, but available observations suggest that it starts during the second or third month of pregnancy and its involution seems complete between 4 and 6 weeks postpartum. As a rule, deciduosis does not give rise to clinical symptoms. Abdominal pain similar to appendicitis, intra-abdominal haemorrhages and haematuria has only very rarely been observed. Markou et al. [37] examined 307 consecutive women at the time of Caesarean section and obtained biopsies from all $(n=31)$ subjects who were noted to have a macroscopic peritoneal lesion. All biopsies showed histological evidence of decidualization. Women with visible deciduosis were more likely to report abdominal pain during pregnancy, but the finding of deciduosis was not linked to preeclampsia, preterm labour or fetal growth restriction. In this study, deciduosis was not related to endometriosis. In this group, the occurrence of pain may be secondary to subclinical hemoperitoneum or to degenerative changes during the regression phase of these lesions.

\section{Mechanisms of Ectopic Decidual Bleeding}

We have previously reported that IVF in women with endometriosis increases the risk of SHiP [2]. Emerging evidence suggests that endometriosis is associated with progesterone resistance characterized by the suboptimal expression of target genes [38]. Therefore, it is tempting 
to speculate that "functional" progesterone withdrawal triggers the involution of the decidual phenotype of the ectopic endometrium surrounding distended parametrial arterioles, leading to peritoneal bleeding of unpredictable severity [39].

In recent years, molecular mechanisms of decidual uterine spiral arteries remodelling in early pregnancy have been investigated. These involve a coordinated series of events, including the creation of a decidual immune cell environment, vascular cell disruption and loss. This is followed by extra villous trophoblast colonization and completion by mid-pregnancy. Smith et al. [40] performed a detailed analysis of the spatial and temporal loss of vascular extracellular matrix in the walls of remodelling decidual spiral artery in early pregnancy. They immuno-stained serial sections of these vessels for a panel of extracellular matrix markers and showed that the initial stages of spiral artery remodelling are characterized by the loss of laminin, elastin, fibrillin, collagen types III, IV, and VI from the basement membrane, vascular media and/or adventitia, and surrounding decidual stromal cells. Loss of extracellular matrix correlated with disruption and disorganization of vascular smooth muscle cells. The majority of changes occurred prior to extensive colonization of the vessel wall by extravillous trophoblast. Given the co-distribution of uterine natural killer (uNK) cells and decidualized stromal cells, a mutual interaction might provide the correct regulatory environment in case of placentation [41]. The uNK cells and macrophages within remodelling vessels seem to prime decidual vessels for extravillous trophoblast invasion and to play a role in recruiting extravillous trophoblasts to line the vessel wall $[42,43]$. However, no information is available on the presence or potential role of uNK cells in ectopic decidualization. While plasma progesterone levels remain elevated throughout human pregnancy, as mentioned decidual bleeding in pregnancy may be elicited by a functional progesterone withdrawal, as indicated by significantly reduced decidual cell nuclear expression of progesterone receptor-A and -B. Functional withdrawal of progesterone results in increased phosphoERK1/2 pathway initiating decidual bleeding and causing obstetrical complications such as abruption-induced preterm delivery [44]. Mechanical as well as cellular changes can contribute to the occurrence of SHiP. Changes in vessel wall can lead to weakening and increased predisposition to bleeding in response to trauma or increased pressure and can also render the vessels more friable resulting in difficulty in obtaining haemostasis. On the other hand, regression of deciduosis can itselflead to increased susceptibility and possibly vascular breakdown.

Decidual Bleeding in Pregnancy
Subclinical Decidual Bleeding as a Potential Risk Factor for Preterm Birth

A subset of patients with preterm labour has vascular lesions of the placental bed, including failure of physiological remodelling of the myometrial spiral arteries [34, $45]$, a lesion that is common in preeclampsia. Understanding why some women with these vascular lesion and abnormal angiogenic profile develop preeclampsia and others preterm labour can provide insight into the pathophysiology of both conditions [46]. Pathogenetic mechanisms implicated in these disorders include defective deep placentation, oxidative and endoplasmic reticulum stress, autoantibodies to type-1 angiotensin-II receptor, platelet and thrombin activation, intravascular inflammation, endothelial dysfunction and the presence of an antiangiogenic state, among which an imbalance of angiogenesis has emerged as one of the most important factors [47]. Premature decidual senescence without progesterone withdrawal has been implicated in placentation disorders including preterm birth. The localization, severity and timing of the angiogenic imbalance, together with maternal susceptibility such as in the presence of endometriosis, may determine the clinical presentation. Recently, Marcellin et al. [48] demonstrated that decidua in women with endometriosis is able to generate endometriotic-like lesions in contact with the fetal membranes and found significant deregulation for genes know to be enriched in processes involved among others in neoangiogenesis.

In a retrospective case study of preterm placentas, Salafia et al. [49] suggested a relation between decidual hemosiderin deposition in the placenta or membranes and preterm delivery. A total of 196 of 462 (43\%) preterm placentas or membranes had any decidual hemosiderin compared with one of $108(0.8 \%)$ at term $(p<0.00001)$. Sakata et al. [50] reviewed recent advances in hemo/ironmediated signalling. Decidual haemorrhage may result in high levels of free heme and iron. Several important preterm birth-specific genes and proteins overlap with those known to be regulated by iron. Free iron oxidatively modifies lipid and protein, leading to DNA and cell damage. Collectively, decidual haemorrhage and inflammation are considered to be major contributors to the pathogenesis of preterm birth. Although the majority of patients with hemosiderin deposition had no history of gestational bleeding, this is an area where more research is needed.

The phenomenon of ectopic decidualization has traditionally been regarded as benign, but accumulating evidence suggests the need for systematic studies to further our understanding of the condition and its significance.

Gynecol Obstet Invest 2017;82:313-321 DOI: $10.1159 / 000468933$ 


\section{Conclusion}

Available evidence suggests that during pregnancy a link exists between ectopic decidualization, particularly that occurring in endometriotic foci, and the occurrence of SHiP. Alterations in vessels' walls have been demonstrated in the few cases where relevant biopsies were obtained and examined. Indeed, it seems that arterioles can become modified in the absence of trophoblast. There is a need to carefully examine vascular alterations at the site of bleeding leading to SHiP to gain information on the pathophysiology of this serious complication. Finally, whereas there are indications that subclinical decidual bleeding may be a potential risk factor for preterm labour, further clinical, pathological and molecular investigations are required.

\section{Disclosure Statement}

The authors report no conflict of interest. No financial support was provided.

\section{References}

1 Leone Roberti Maggiore U, Ferrero S, Mangili G, Bergamini A, Inversetti A, Giorgione V, Viganò $\mathrm{P}$, Candiani M: A systematic review on endometriosis during pregnancy: diagnosis, misdiagnosis, complications and outcomes. Hum Reprod Update 2016;22:70103.

2 Brosens IA, Lier MC, Mijatovic V, Habiba M, Benagiano G: Severe spontaneous hemoperitoneum in pregnancy may be linked to in vitro fertilization in patients with endometriosis: a systematic review. Fertil Steril 2016;106: 692-703.

3 Hodgkinson CP, Christensen RC: Hemorrhage from ruptured utero-ovarian veins during pregnancy: report of 3 cases and review of the literature. Am J Obst Gynecol 1950;59: 1112-1117.

4 Ginsburg KA, Valdes C, Schnider G: Spontaneous utero-ovarian vessel rupture during pregnancy: three case reports and a review of the literature. Obstet Gynecol 1987;69(3 pt 2):474-476.

5 Inoue T, Moriwaki T, Niki I: Endometriosis and spontaneous rupture of utero-ovarian vessels during pregnancy. Lancet 1992;340: 240-241.

6 Mizumoto Y, Furuya K, Kikuchi Y, Aida S, Hyakutake K, Tamai S, Nagata I: Spontaneous rupture of the uterine vessels in a pregnancy complicated by endometriosis. Acta Obstet Gynecol Scand 1996;75:860-862.

7 Swaegers MC, Hauspy JJ, Buytaert PM, De Maeseneer MG: Spontaneous rupture of the uterine artery in pregnancy. Eur J Obstet Gynecol Reprod Biol 1997;75:145-146.

8 Ismail KM, Shervington J: Hemoperitoneum secondary to pelvic endometriosis in pregnancy. Int J Gynaecol Obstet 1999;67:107108.

9 Janicki TI, David LJ, Skaf R: Massive and acute hemoperitoneum due to rupture of the uterine artery by erosion from an endometriotic lesion. Fertil Steril 2002;78:879-881.

10 Hashimoto K, Tabata C, Ueno Y, Fukuda H, Shimoya K, Murata Y: Spontaneous rupture of uterine surface varicose veins in pregnan- cy: a case report. J Reprod Med 2006;51:722724.

11 Fiori O, Prugnolles H, Darai E, Uzan S, Berkane $\mathrm{N}$ : Spontaneous uterine artery rupture during pregnancy in a woman with sickle cell disease: a case report. J Reprod Med 2007;52:657-658.

12 De Vincenzo R, Zannoni GF, Ricci C, Conte C, Masciullo V: Bowel endometriosis with hemoperitoneum complicating pregnancy. J Endometriosis 2011;5:166-169.

13 Robboy SJ, Mutter GL, Prat J, Bentley RC, Russel P, Anderson MC: Robboy's Pathology of the Female Reproductive Tract, ed II. Amsterdam, Churchill Livingstone, Elsevier, 2008, p 579.

14 Lier MCI, Malik RF, van Waesberghe JHTM, Maas JW, van Rumpt-van de Geest DA, Coppus SF, Berger JP, van Rijn BB, Janssen PF, de Boer MA, de Vries JIP, Jansen FW, Brosens IA, Lambalk CB, Mijatovic V: Spontaneous haemoperitoneum in pregnancy and endometriosis: a case series. BJOG 2017;124:306-312.

15 Loh MJ, Wee JY, Teo SB: Endometriosis in a twin pregnancy leading to massive hemoperitoneum and intrauterine death: a case report. J Endometriosis 2015;7:86-88.

16 Cozzolino M, Corioni S, Maggio L, Sorbi F, Guaschino S, Fambrini M: Endometriosis-related hemoperitoneum in pregnancy: a diagnosis to keep in mind. Ochsner J 2015;15: 262-264.

17 Aggarwal I, Tan P, Mathur M: Decidualised fallopian tube endometriotic implant causing spontaneous haemoperitoneum in a twin pregnancy. BMJ Case Rep 2014;pii:bcr2014205317.

18 Kondoh E, Shimizu M, Kakui K, Mikami Y, Tatsumi K, Konishi I: Deciduosis can cause remarkable leukocytosis and obscure abdominal pain. J Obstet Gynaecol Res 2012;38: 1376-1378.

19 Reif P, Schöll W, Klaritsch P, Lang U: Rupture of endometriotic ovarian cyst causes acute hemoperitoneum in twin pregnancy. Fertil Steril 2011;95:2125.e1-e3.

20 Brouckaert OM, Oostenveld E, Quartero H: Spontaneous hemoperitoneum and fetal demise in a nulliparous woman requiring hys- terectomy with fetus in situ. Int J Gynaecol Obstet 2010;110:273.

21 Bouet PE, Sentilhes L, Lefebvre-Lacoeuille C, Catala L, Gillard P, Descamps P: Endometriosis and spontaneous rupture of uterine vessels with hemothorax during pregnancy. Eur J Obstet Gynecol Reprod Biol 2009;144:95-96.

22 Grunewald C, Jördens A: Intra-abdominal hemorrhage due to previously unknown endometriosis in the third trimester of pregnancy with uneventful neonatal outcome: a case report. Eur J Obstet Gynecol Reprod Biol 2010;148:204-205.

23 Katorza E, Soriano D, Stockheim D, Mashiach R, Zolti M, Seidman DS, Schiff E, Goldenberg M: Severe intraabdominal bleeding caused by endometriotic lesions during the third trimester of pregnancy. Am J Obstet Gynecol 2007;197:501.e1-e4.

24 Aziz U, Kulkarni A, Lazic D, Cullimore JE: Spontaneous rupture of the uterine vessels in pregnancy. Obstet Gynecol 2004;103:10891091.

25 Doyle GB, Phillips DL: Fatal intraperitoneal haemorrhage during pregnancy. J Obstet Gynaecol Br Emp 1957;64:270-271.

26 Zhang Z, Lou J: Hemoperitoneum after administration of prostaglandin E2 for induction of labour. Case Rep Obstet Gynecol 2015; 2015:659274.

27 Boztosun A, Sümer D, Çetin M, Ali Çetin A: Idiopathic spontaneous hemoperitoneum during early postpartum period: case report. Turkiye Klinikleri J Med Sci 2012;32:17181720.

28 Gao JL, Lortie K, Singh SS: Laparoscopic internal iliac artery ligation for postpartum spontaneous hemoperitoneum. J Obstet Gynaecol Can 2010;32:1172-1175.

29 O'Leary SM: Ectopic decidualization causing massive postpartum intraperitoneal hemorrhage. Obstet Gynecol 2006;108(3 pt 2):776779.

30 Richter MA, Choudhry A, Barton JJ, Merrick RE: Bleeding ectopic decidua as a cause of intraabdominal hemorrhage. A case report. J Reprod Med 1983;28:430-432. 
31 Sabatelle R, Winger E: Postpartum intraabdominal hemorrhage caused by ectopic deciduosis. Obstet Gynecol 1973;41:873-875.

32 Hulme-Moir I, Ross MS: A case of early postpartum abdominal pain due to haemorrhagic deciduosis peritonei. J Obstet Gynaecol $\mathrm{Br}$ Commonw 1969;76:746-749.

33 Craven CM, Morgan T, Ward K: Decidual spiral artery remodelling begins before cellular interaction with cytotrophoblasts. Placenta $1998 ; 19: 241-252$.

34 Brosens I, Pijnenborg R, Vercruysse L, Romero R: The "Great Obstetrical Syndromes" are associated with disorders of deep placentation. Am J Obstet Gynecol 2011;204:193-201.

35 Zaytsev P, Taxy JB: Pregnancy-associated ectopic decidua. Am J Surg Pathol 1987;11:526530

36 Büttner A, Bässler R, Theele C: Pregnancyassociated ectopic decidua (deciduosis) of the greater omentum. An analysis of 60 biopsies with cases of fibrosing deciduosis and leiomyomatosis peritonealis disseminata. Pathol Res Pract 1993; 189:352-359.

37 Markou GA, Goubin-Versini I, Carbunaru OM, Karatzios C, Muray JM, Fysekidis M: Macroscopic deciduosis in pregnancy is finally a common entity. Eur J Obstet Gynecol Reprod Biol 2016;197:54-58.

38 Bulun SE, Cheng YH, Yin P, Imir G, Utsunomiya $\mathrm{H}$, Attar E, Innes J, Julie Kim J: Progesterone resistance in endometriosis: link to failure to metabolize estradiol. Mol Cell Endocrinol 2006;248:94-103.
39 Brosens IA, Fusi L, Brosens JJ: Endometriosis is a risk factor for spontaneous hemoperitoneum during pregnancy. Fertil Steril 2009;92: 1243-1245.

40 Smith SD, Choudhury RH, Matos P, Horn JA, Lye SJ, Dunk CE, Aplin JD, Jones RL, Harris LK: Changes in vascular extracellular matrix composition during decidual spiral arteriole remodeling in early human pregnancy. Histol Histopathol 2016;31:557-571.

41 Hanna J, Goldman-Wohl D, Hamani Y, Avraham I, Greenfield C, Natanson-Yaron S, Prus D, Cohen-Daniel L, Arnon TI, Manaster I, Gazit R, Yutkin V, Benharroch D, Porgador A, Keshet E, Yagel S, Mandelboim O: Decidual NK cells regulate key developmental processes at the human fetal-maternal interface. Nat Med 2006;12:1065-1074.

42 Dunn CL, Kelly RW, Critchley HO: Decidualization of the human endometrial stromal cell: an enigmatic transformation. Reprod BioMed Online 2003;7:151-161.

43 Lash GE, Otun HA, Innes BA, Kirkley M, De Oliveira L, Searle RF, Robson SC, Bulmer JN: Interferon-gamma inhibits extravillous trophoblast cell invasion by a mechanism that involves both changes in apoptosis and protease levels. FASEB J 2006;20:2512-2518.

44 Lockwood CJ, Kayisli UA, Stocco C, Murk W, Vatandaslar E, Buchwalder LF, Schatz F: Abruption-induced preterm delivery is associated with thrombin-mediated functional progesterone withdrawal in decidual cells. Am J Pathol 2012;181:2138-2148.
45 Kim YM, Bujold E, Chaiworapongsa T, Gomez R, Yoon BH, Thaler HT, Rotmensch S, Romero R: Failure of physiologic transformation of the spiral arteries in patients with preterm labor and intact membranes. Am J Obstet Gynecol 2003;189: 1063-1069.

46 Romero R, Dey SK, Fisher SJ: Preterm labor: one syndrome, many causes. Science 2014; 345:760-765.

47 Chaiworapongsa T, Romero R, Whitten AE, Korzeniewski SJ, Chaemsaithong P, Hernandez-Andrade E, Yeo L, Hassan SS: The use of angiogenic biomarkers in maternal blood to identify which SGA fetuses will require a preterm delivery and mothers who will develop pre-eclampsia. J Matern Fetal Neonatal Med 2016;29:12141228 .

48 Marcellin L, Santulli P, Gogusev J, Lesaffre C, Jacques S, Chapron C, Goffinet F, Vaiman D, Mehats C: Endometriosis also affects the decidua in contact with the fetal membranes during pregnancy. Hum Reprod 2015:30: 392-405.

49 Salafia CM, Pezzullo JC, López-Zeno JA, Simmens S, Minior VK, Vintzileos AM: Placental pathologic features of preterm preeclampsia. Am J Obstet Gynecol 1995; 173: 1097-1105

50 Sakata M, Sado T, Kitanaka T, Naruse K, et al: Iron-dependent oxidative stress as a pathogenesis for preterm birth. Obstet Gynecol Surv 2008;63:651-660. 